\title{
Protein SSX2
}

National Cancer Institute

\section{Source}

National Cancer Institute. Protein SSX2. NCI Thesaurus. Code C97813.

Protein SSX2 (188 aa, $\sim 22 \mathrm{kDa}$ ) is encoded by the human SSX2 and SSX2B genes. This protein may play a role in the modulation of transcription. 